\title{
SOYBEAN SEED GALACTINOL SYNTHASE ACTIVITY AS DETERMINED BY A NOVEL COLORIMETRIC ASSAY
}

\author{
MARLUCI RIBEIRO ${ }^{1}$, CARLOS R. FELIX ${ }^{2}$ AND SILENE DE PAULINO LOZZI ${ }^{3}$. \\ Departamento de Biologia Celular, Universidade de Brasília, Brasília, DF, 70.910.900 , Brazil.
}

\begin{abstract}
Galactinol synthase (GS) is a key enzyme for the biosynthesis of raffinose oligosaccharides (RO) which are the flatulence factors present in soybean seeds and several other legumes. Understanding of soybean seed GS properties is, therefore, of biotechnological interest. The GS enzyme catalyses formation of galactinol and UDP from UDP-gal and myo-inositol. This enzyme is currently assayed by an isotopic method. We have then idealized a more convenient method for GS assay based on the indirect colorimetric determination of the UDP formed which is then hydrolyzed by exogenous apyrase and the resulting Pi quantified by a modification of the colorimetric method of Fiske \& SubbaRow. The color developed is stable, and the method is suitable for detection of very low GS activity. The GS activity profiles of developing soybean seeds determined by the isotopic and the colorimetric methods are closely related. The GS enzyme was partially purified (46-fold) by treatment of seed extract with $\mathrm{MnCl}_{2}$, sequential chromatographies on DEAE-Sepharose, Phenyl-Sepharose CL-4B and Q-Sepharose columns. The crude and the partially purified enzyme showed maximum activity at $\mathrm{pH} 7.0$ and $50{ }^{\circ} \mathrm{C}$. Dithiothreitol and $\mathrm{MnCl}_{2}$ enhanced considerably the activity of the partially purified enzyme. While UDP-glc could be hydrolyzed by the enzyme at a reative activity corresponding to $49 \%$ of that calculated for UDP-gal, UDP-man and sucrose were completely ineffective as alternative substrates.
\end{abstract}

ADDITIONAL INDEX TERMS: Flatulence, galactinol synthase, colorimetric assay, raffinose oligosaccharides.

ABBREVIATIONS - GS, Galactinol synthase; DTT, Dithiothreitol; EDTA, Ethylenediaminetetraacetic acid; HEPES, (N-[2-Hydroxy-ethylpiperazine-N'-[2-ethanesulfonic acid]\}; PMSF, Phenylmethylsulfonyl Fluoride; RO, Raffinose oligosaccharides; SD, Standard deviation; TCA, Trichloroacetic acid; TRIS, Tris(hidroxymethyl) aminomethane; UDP- $\left[\mathrm{U}-{ }^{14} \mathrm{C}\right]$ gal, Uridine 5 'diphospho-[U- $\left.{ }^{14} \mathrm{C}\right]$ galactose; UDP-glc, Uridine diphospho-glucose; UDP-man, Uridine diphospho-manose.

\section{ATIVIDADE DE GALACTINOL SINTASE DE SEMENTE DE SOJA DETERMINADA POR UM NOVO ENSAIO CALORIMÉTRICO}

RESUMO - Galactinol sintase (GS) é a enzima-chave para a biossíntese de oligosacarídeos de rafinose (RO), que são os fatores antinutricionais causadores de flatulência, os quais estão presentes em sementes de soja e em outros legumes. A GS catalisa a formação de galactinol e UDP a partir de UDP-gal e

Received: 23/07/00 - Accepted: 03/10/00

1. Prof . Assistente, M.S. Departamento de Biologia Geral, Universidade Federal de Viçosa, 36.571-000 - Viçosa, MG, Brazil; Bolsista da CAPES; Corresponding author: Fax (31) 899 2549, E-mail: marluci@ mail.ufv.br

2. Prof. Adjunto, Ph.D. , Departamento de Biologia Celular - UnB, Brasília, DF.

3. Prof . Adjunto, D.S., Departamento de Genética e Morfologia - UnB, Brasília, DF. 
mioinositol. A atividade dessa enzima é determinada atualmente pelo método radioisotópico que, apesar de adequado tecnicamente, apresenta vários inconvenientes, tais como a necessidade de substrato de alto custo, bem como de cuidados adicionais e serviços especializados para descarte dos resíduos radioativos. Assim, desenvolveu-se um método colorimétrico alternativo ao método radioisotópico, baseado na determinação colorimétrica indireta do UDP formado pela hidrólise enzimática (apirase) desse nucleotídeo e determinação do Pi resultante pelo método de Fiske \& SubbaRow, com modificações. A cor desenvolvida é estável e o método é sensível para detecção de quantidades nanomolares de Pi.

Os perfis de atividade da GS em sementes de soja em diferentes fases de desenvolvimento, determinados pelos métodos colorimétrico e radioisotópico, são semelhantes. Adicionalmente, a GS de sementes de soja foi purificada (46-vezes) por tratamento do extrato das sementes com $\mathrm{MnCl}_{2}$, e uma seqüência de cromatografias em colunas de DEAE-Sepharose, Phenyl-Sepharose CL-4B e Q-Sepharose. As atividades de GS no extrato bruto e na amostra parcialmente purificada foram máximas em $\mathrm{pH} 7.0 \mathrm{e}$ $50{ }^{\circ} \mathrm{C}$. Ditiotreitol e $\mathrm{MnCl}_{2}$ aumentaram consideravelmente a atividade da enzima parcialmente purificada. Enquanto UDP-glc pode ser hidrolisado pela enzima com uma atividade relativa correspondendo a 49\% da atividade contra UDP-gal, UDP-man e sacarose foram completamente ineficazes como substratos alternativos. Os valores de $\mathrm{K}_{\mathrm{M}}$ para conversão de UDP-gal e mio-inositol foram de 2,0 mM e 2,93 mM, respectivamente, determinados pelo método de Lineaweaver-Burk.

TERMOS ADICIONAIS PARA INDEXAÇÃO: Flatulência, galactinol sintase, ensaio colorimétrico, oligosacarídeos de rafinose.

\section{INTRODUCTION}

The raffinose oligosaccharides $(\mathrm{RO})$ are present in various higher plants (Lee et al., 1970). They are second only to sucrose in abundance in legume seeds (Dey, 1985). Their primary role is thought to be reserve carbohydrates for short- and long-term purposes and for transport (Chatterton et al., 1990, Dini et al., 1989, Pharr and Sox, 1984), and protection of plants against cold and seeds against desiccation (Kandler and Hopf, 1980; Saravitz et al., 1987). Nevertheless, the RO have been implicated as causative factors for flatulence after ingestion of food containing soybean meals (Rackis et al., 1970).

The biosynthesis of RO [ $\alpha$-D-galatosyl$1,6)_{n}$-sucrose] occurs via sequential transfers of galactosyl units to sucrose mediated by specific transferase enzymes. The galactosyl donor is galactinol (1L-1-O- $\alpha$-D-galactopyranosyl-myoinositol) which is synthesized in the reaction UDPgal + myo-inositol $\rightarrow$ UDP + galactinol, catalyzed by galactinol synthase (UDP- $\alpha$-D-gal:1L-myoinositol-1-O- $\alpha$-D-galactopyranosyltransferase; EC 2.4.1.123). The galactinol synthase (GS) is believed to be a key enzyme in the biosynthetic pathway of RO. It is the first enzyme to commit sucrose to biosynthesis of RO and is, therefore, a metabolic control point in carbon partitioning between sucrose and RO. GS activity in soybean seeds increases immediately prior to the beginning of the accumulation of RO, and shows a positive correlation with levels of these oligosaccharides (Saravitz et al., 1987; Handley et al., 1983; Lowell and Kuo, 1989). Thus, manipulation of GS in vivo may lead to understanding of the physiological role of the RO in plants and reduction of flatulence factors in legumes.

GS is currently assayed by a radioisotopic method originally described by Handley and Pharr (1982), and modified by Liu et al., (1995). However, this radioisotopic method is expensive and requires special handling and disposal mehtods for radioactive wastes. To facilitate the assay of GS, we have developed a colorimetric method which is more convenient for routine use. This assay is based on the indirect quantification of the UDP formed from myoinositol and UDP-gal by the action of GS. The resulting UDP is then hydrolyzed to UMP and Pi by exogenous insect or potato apyrase, with subsequent quantification of Pi by the colorimetric method of Fiske and SubbaRow (1925) with modifications. Here, we report on the reliability of 
this method, as well as on the GS activity profile of soybean seeds during development in the field, as determined by both the radioisotopic method and the proposed colorimetric method.

Although GS has been purified from Cucurbita pepo (Webb, 1982; Smith et al., 1991; Liu et al., 1995) and kidney bean cotyledons (Liu et al., 1995), purification of soybean seed GS has not been reported yet. A partial purification protocol for soybean seed GS and some of the its kinetic properties are therefore reported here.

\section{MATERIALS AND METHODS}

Chemicals - Potato apyrase (grade V), UDP, UDP-gal, myo-inositol, HEPES, DTT, Fiske and SubbaRow reducer, Dowex-1(1X4-100 chloride strongly basic anion exchange resin), hydrophilic scintillation solution, TCA, $\mathrm{MnCl}_{2}$, and PMSF were purchased from Sigma. UDP-[U- $\left.{ }^{14} \mathrm{C}\right]$ gal was purchased from Amersham. All other chemicals were of analytical grade.

Insect apyrase - Insect apyrase was prepared using 200 pairs of pink salivary glands from the 5th instar larvae of Rhodnius prolixus (laboratory stock). The glands were excised from the heads, homogenized in $200 \mu \mathrm{L}$ of water and then centrifuged at $3,000 \times \mathrm{g}$ for $10 \mathrm{~min}$ at $4{ }^{\circ} \mathrm{C}$. The supernatant (crude insect apyrase extract) was assayed for its apyrase activity (Sarkis et al., 1986) and stored at $-20{ }^{\circ} \mathrm{C}$ until use. One unit of apyrase activity corresponds to the amount of protein necessary to hydrolyze one $\mu \mathrm{mol}$ of UDP per minute at $\mathrm{pH} 7.5$ and $37^{\circ} \mathrm{C}$.

Extraction - Soybean plants (Glycine max L. Merril, var. FT CRISTALINA RCH) were grown under field conditions from mature seeds. Plants were watered daily. After beginning of flowering, the seeds were harvested at 5-day intervals for 30 days and used either for determination of fresh and dry weights, or stored at $-20{ }^{\circ} \mathrm{C}$ until use. For preparation of GS extracts the seedcoats and axes were removed, and the cotyledons (5g) were ground in a mortar with $10 \mathrm{~mL}$ of cold extraction buffer (50 mM HEPES, pH 7.0, containing $1 \mathrm{mM}$ DTT and $1 \mathrm{mM}$ PMSF). The homogenate was then centrifuged at $28,000 \times \mathrm{g}$ for $30 \mathrm{~min}$ at $4{ }^{\circ} \mathrm{C}$ and the supernatant (GS extract) used for GS assays.

Dry weight determination. Seeds were weighed and dried in a closed chamber at $70^{\circ} \mathrm{C}$ until constant weight.

\section{GS Assay}

Radioisotopic method - The radioisotopic assay was performed as described by Handley and Pharr (1982), with slight modifications. The reaction mixture contained $50 \mu \mathrm{L}$ of galactinol synthase extract, $60 \mathrm{mM}$ myo-inositol, $2 \mathrm{mM}$ DTT, 50 $\mathrm{mM}$ HEPES buffer ( $\mathrm{pH} 7.0$ ), $4 \mathrm{mM} \mathrm{MnCl}_{2}, 20$ $\mu \mathrm{g}$ of bovine serum albumin and $4 \mathrm{mM}$ UDP-[U$\left.{ }^{14} \mathrm{C}\right]$ gal $\left(0.25 \mu \mathrm{Ci} \mu \mathrm{mol}^{-1}\right)$ in a total volume of $100 \mu \mathrm{L}$. The reaction was conducted for $30 \mathrm{~min}$ at $32{ }^{\circ} \mathrm{C}$ and terminated by the addition of 400 $\mu \mathrm{L}$ of $100 \%$ ethanol. Unreacted UDP-[U- $\left.{ }^{14} \mathrm{C}\right] \mathrm{gal}$ was removed by adding $400 \mu \mathrm{L}$ of a Dowex-1 anion exchange resin slurry $\left(0.6 \mathrm{~g} \mathrm{~mL}^{-1}\right)$ to each tube and incubation for $50 \mathrm{~min}$ under agitation $(200 \mathrm{rpm})$. The tubes were then centrifuged for $10 \mathrm{~min}$ at $12.000 \mathrm{rpm}$ and the supernatant collected. A $50 \mu \mathrm{L}$ aliquot of this supernatant was pipetted into $1 \mathrm{~cm}^{2}$ filter paper discs (Whatman $n^{\circ}$ 2) which were then dried and placed in scintillation counter flasks containing 6 $\mathrm{mL}$ of a hydrophilic scintillation solution. The radioactivity was determined in a Beckman liquid scintillation counter with an efficiency of $75 \%$. Reaction mixtures containing no myoinositol were used as controls. Each assay was done in triplicates. Control counts were subtracted from test counts and enzyme activity expressed as $\mu \mathrm{mol}$ of galactinol formed, considering the specific activity of the UDP-[U${ }^{14} \mathrm{C}$ ggal. According to Handley and Pharr (1982), the limit of detection of this assay is $100 \mathrm{dpm}$ above background or 0.5 nmoles galactinol $\mathrm{mL}$ enzyme ${ }^{-1} \mathrm{~min}^{-1}$. 
Colorimetric method - The colorimetric assay was performed using the same reaction mixture for the isotopic method of Handley and Pharr (1982) as described above, using UDP-gal instead of UDP-[U- $\left.{ }^{14} \mathrm{C}\right] \mathrm{gal}$, with modifications. The reaction was allowed to proceed for $30 \mathrm{~min}$ (except when stated) at $32{ }^{\circ} \mathrm{C}$, and terminated by placing the tubes in boiling water for $2 \mathrm{~min}$. To each tube were added $500 \mu \mathrm{L}$ of water, $10 \mu \mathrm{L}(0.3 \mathrm{U})$ of insect or potato apyrase solution, and $150 \mu \mathrm{L}$ of apyrase reaction mixture (Tris- $\mathrm{HCl}$ buffer, $250 \mathrm{mM}, \mathrm{pH}$ 7.5, containing $25 \mathrm{mM} \mathrm{KCl}, 7.5 \mathrm{mM} \mathrm{CaCl}_{2}$, $0.5 \mathrm{mM}$ EDTA-Na, and $50 \mathrm{mM}$ glucose) (Sarkis et al., 1986). After incubation for $10 \mathrm{~min}$ at $37^{\circ} \mathrm{C}$, the apyrase reaction was stopped by addition of $60 \mu \mathrm{L}$ of $75 \%$ TCA. The tubes were then cooled on ice for $10 \mathrm{~min}$, centrifuged at 3,000 $\mathrm{x} g$ for $10 \mathrm{~min}$ and the amount of Pi in the supernatant was determined by a modified Fiske and SubbaRow (1925) protocol. To each tube were added $100 \mu \mathrm{L}$ of $2.5 \%$ ammonium molybdate dissolved in $2 \mathrm{~N} \mathrm{HCl}$ and $40 \mu \mathrm{L}$ of Fiske and SubbaRow reducer. After 2 min at room temperature, $40 \mu \mathrm{L}$ of a $34 \%$ sodium citrate. $2 \mathrm{H}_{2} \mathrm{O}$ solution were added to the tubes, and absorbance was immediately measured at $660 \mathrm{~nm}$. The amount of UDP formed by the GS was determined using a standard curve constructed with UDP hydrolyzed by the apyrase, and correlated to the amount of UDP produced by the galactinol synthase. One unit (U) of GS activity corresponds to the amount of protein necessary to produce one $\mu \mathrm{mol}$ of UDP per minute. Each assay was done in triplicate. Control tests were performed by omitting myo-inositol from the galactinol synthase reaction mixture.

GS purification - Cotyledons (150 g) from seeds harvested 70 days after beginning of flowering were pre-incubated with $600 \mathrm{~mL}$ of $20 \%$ hexane for $30 \mathrm{~min}$ and washed immediately with $4 \mathrm{~L}$ of cold water. The cotyledons were then ground in a mortar with $300 \mathrm{~mL}$ of cold extraction buffer (50 $\mathrm{mM}$ HEPES, $\mathrm{pH}$ 7.0, containing $1 \mathrm{mM}$ DTT and 1 $\mathrm{mM}$ PMSF). The homogenate was centrifuged at $28,000 \times \mathrm{g}$ for $30 \mathrm{~min}$ at $4{ }^{\circ} \mathrm{C} . \mathrm{MnCl}_{2}(1 \mathrm{M}$ solution) was added to the resulting supernatant (GS extract) to a final concentration of $25 \mathrm{mM}$.
The mixture was then centrifuged at 28,000 $\mathrm{x} g$ for $30 \mathrm{~min}$ and the supernatant dialyzed overnight against water and centrifuged again at 28,000 $\mathrm{x} g$ for $20 \mathrm{~min}$. This last supernatant was applied into a DEAE-Sepharose column $(2.6 \times 14 \mathrm{~cm})$ previously equilibrated with running buffer (50 mM MOPS $\mathrm{Na}$, pH 7.0, containing $2 \mathrm{mM}$ DTT). Bound proteins were initially eluted with $300 \mathrm{~mL}$ of the MOPS running buffer followed by elution with a linear gradient formed with $180 \mathrm{~mL}$ of the running buffer and $180 \mathrm{~mL}$ of the same buffer containing $0.5 \mathrm{M} \mathrm{NaCl}$. Samples of $6 \mathrm{~mL}$ were collected at a flow rate of $90 \mathrm{~mL} \mathrm{~h}^{-1}$. Fractions containing GS activity were pooled, supplemented with solid $\left(\mathrm{NH}_{4}\right)_{2} \mathrm{SO}_{4}$ to a final concentration of $1 \mathrm{M}$ and applied to a Phenyl-Sepharose 4B column $(2.6 \mathrm{x}$ $14 \mathrm{~cm})$ pre-equilibrated with $1 \mathrm{M}\left(\mathrm{NH}_{4}\right)_{2} \mathrm{SO}_{4}$ dissolved in MOPS running buffer. Elution was carried out with $150 \mathrm{~mL}$ of $1 \mathrm{M}\left(\mathrm{NH}_{4}\right)_{2} \mathrm{SO}_{4}$ dissolved in MOPS running buffer, followed by a linear negative gradient formed with $150 \mathrm{~mL}$ of MOPS running buffer containing $1 \mathrm{M}\left(\mathrm{NH}_{4}\right)_{2} \mathrm{SO}_{4}$ and $150 \mathrm{~mL}$ of the same buffer. The column was further eluted with $150 \mathrm{~mL}$ of MOPS running buffer. Elution was performed at a flow rate of 120 $\mathrm{mL} \mathrm{h}^{-1}$. Samples of $6 \mathrm{~mL}$ were collected. Active fractions were pooled, dialyzed overnight against water and applied into a Q-Sepharose column (2.6 $\mathrm{x} 14 \mathrm{~cm}$ ) previously equilibrated with running buffer. Proteins were eluted with $110 \mathrm{~mL}$ of running buffer followed by a linear gradient formed with $150 \mathrm{~mL}$ of the running buffer and 150 $\mathrm{mL}$ of the same buffer containing $0.5 \mathrm{M}$ of $\mathrm{NaCl}$. Samples of $6 \mathrm{~mL}$ were collected at a flow rate of $90 \mathrm{~mL} \mathrm{~h}^{-1}$. Active fractions were pooled, dialyzed against water for $6 \mathrm{~h}$ at $4{ }^{\circ} \mathrm{C}$, and used for kinetic studies or stored at $-20{ }^{\circ} \mathrm{C}$ until use. All purification steps were carried out on ice or at $4{ }^{\circ} \mathrm{C}$. GS activity was determined by the colorimetric method.

\section{Electrophoresis}

Electrophoresis was carried out in $12 \%$ sodium dodecyl sulphate polyacrylamide gel (SDS-PAGE) according to Laemmli (1970). Proteins were stained with silver reagent (Blum et al,. 1987 ). 


\section{Kinetics}

Initial rates of substrate hydrolysis were determined by the colorimetric method. The buffers $(50 \mathrm{mM})$ used for optimal $\mathrm{pH}$ determination were Na-acetate buffer $(\mathrm{pH} 4-6)$, BES-Na (pH 6.5-7), BICINE-Na (pH 7.6-8.9). $\mathrm{K}_{\mathrm{M}}$ values for UDP-galactose hydrolysis and myoinositol utilization were determined by the Lineweaver-Burk plot, and by an algorithm for least squares estimation of non-linear parameters (Marquardt, 1979).

\section{RESULTS AND DISCUSSION}

GS catalyzes the reaction UDP-gal + myo-inositol $\rightarrow$ galactinol + UDP. Although this enzyme is considered of biotechnological interest, there is no chemical method available for its specific assay. The isotopic method (Handley and Pharr, 1982) requires ${ }^{14} \mathrm{C}$-labeled UDP-gal as substrate; although extremely sensitive, it is expensive and the radioactive wastes require special handling and disposal methods. We have, therefore, developed a novel GS assay based on the colorimetric quantification (Fiske and SubbaRow, 1925) of the Pi produced by the enzymatic hydrolysis of the UDP formed by the GS enzyme. As shown in Figure 1 absorbance values at $660 \mathrm{~nm}$ are proportional to the amount of Pi up to $600 \mu \mathrm{M}$. Phosphate ions linked to UDP and UDP-gal do not react with the Fiske and SubbaRow reagent even at concentrations as high as $800 \mu \mathrm{M}$ (Figure 1). However, UDP is promptly hydrolyzed by insect or potato apyrase (ATP-diphosphohydrolase; ATPase; EC 3.6.1.5) which catalyzes the hydrolysis of the $\gamma$ - and $\beta$-phosphate residues from triphospho- and diphosphonucleosides (Meyerhof, 1945). The Rhodnius prolixus crude saliva is devoid of 5'nucleotidase, inorganic pyrophosphatase, phosphatase and adenylate kinase activities but hydrolyzes ATP and ADP to the corresponding diphospho- and monophosphatonucleotide (Sarkis et al., 1986), and therefore insect saliva apyrase was used throughout this work. As shown in Figure 1 the absorbance curve obtained with UDP hydrolyzed with apyrase matches exactly the standard curve constructed with $\mathrm{KH}_{2} \mathrm{PO}_{4}$. However, no color is developed when the UDP is replaced by UDP-gal (Figure 1) or mononucleotide phosphates (not shown). The standard deviation values determined for the GS assay were always less than $10 \%$ of the mean values, reflecting the reliability of our colorimetric assay method. Additional experiments have shown that the insect enzyme may be successfully replaced by potato apyrase but not by alkaline phosphatase which was shown to be much less effective than the apyrases (data not shown).

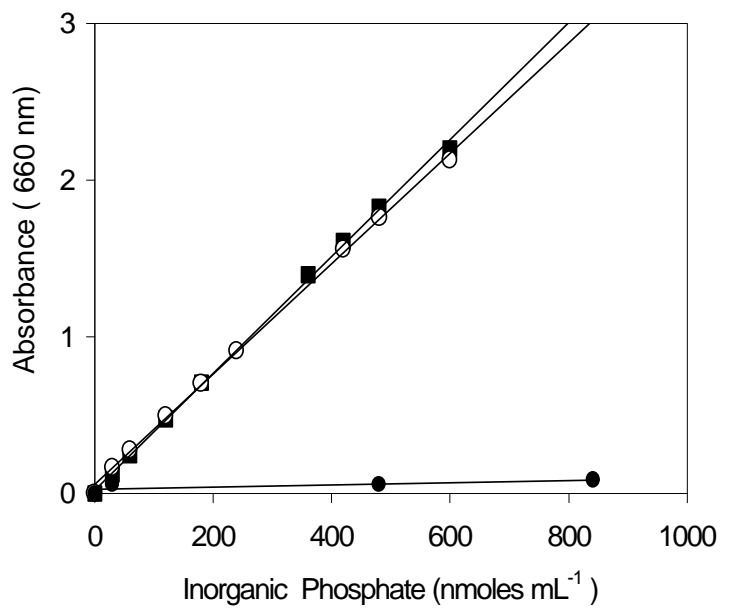

FIGURE 1 - Color intensity (absorbance at 660nm) of the reaction mixture containing different concentrations (nM) of inorganic phosphate from $\mathrm{KH}_{2} \mathrm{PO}_{4}$. (口), or resulting from hydrolysis of UDP (O) or UDP-gal with insect apyrase $(\bullet)$.

The GS-apyrase coupled reaction was shown to be of first order with variable volumes (0-50L) of GS extract, and to be linear over a 60 min pereiod of time (data not shown). The possibility that sucrose phosphate synthase or sucrose synthase may account for the observed color development can be ruled out as no color developed above the background levels when UDP-gal was omitted from the reaction mixture, or sucrose was added as substrate. UDP-glc acts as substrate but with low specificity. However, as UDP is the product of reactions catalyzed by sucrose phosphate synthase and sucrose synthase 
our colorimetric assay may be also adapted and used for assay of these enzymes in the presence of the corresponding substrates.

Quantification of the $\mathrm{Pi}$ formed by enzymatic hydrolysis of the UDP produced in the GS reaction mixture required minor modifications of the method of Fiske and SubbaRow (1925) which describes the dissolution of the ammonium molybdate in $5 \mathrm{~N} \mathrm{HCl}$. Under our assay conditions, $\mathrm{HCl}$ at the concentration of $5 \mathrm{~N}$ induced color development resulting from the acid hydrolysis of organophosphate compounds. However, at the concentration of $2 \mathrm{~N}$, the $\mathrm{HCl}$ used to prepare the ammonium molybdate acidic solution did not induce additional unspecific color development. The color developed was only fairly stable, but addition of Na-citrate as recommended by Lanzetta et al. (1979) for determination of Pi considerably improved stability of the dye-phosphomolybdate complex. Additionallly, it has the advantage of being insensitive to any newly released phosphate by acid hydrolysis of organophosphate compounds.

The profiles of GS activity determined for soybean seeds of different ages by both the isotopic method (Handley and Pharr, 1982) and the novel colorimetric method are closely related (Figure 2), indicating that the colorimetric method is reliable for quantification of GS activity. The activity levels in developing seeds varied with the amount of dry matter present in the seeds. Highest activity was observed for the yellow colored seeds showing $42 \%$ dry matter, corresponding to the 6.5 reproductive growth stage (Fehr et al., 1971). These results are in agreement with those previously reported by Lowell and Kuo (1989). GS has been considered an important regulator of carbon partitioning between sucrose and raffinose and stachyose in developing soybean seeds (Saravitz et al., 1987).

Soybean seed GS was partially purified by treatment with $\mathrm{MnCl}_{2}$ and a sequence of chromatographic procedures. The elution profile of the GS on a Q-Sepharose column, the last column of the sequence, is shown in Figure 3. A summary of the purification steps is shown in Table 1. The

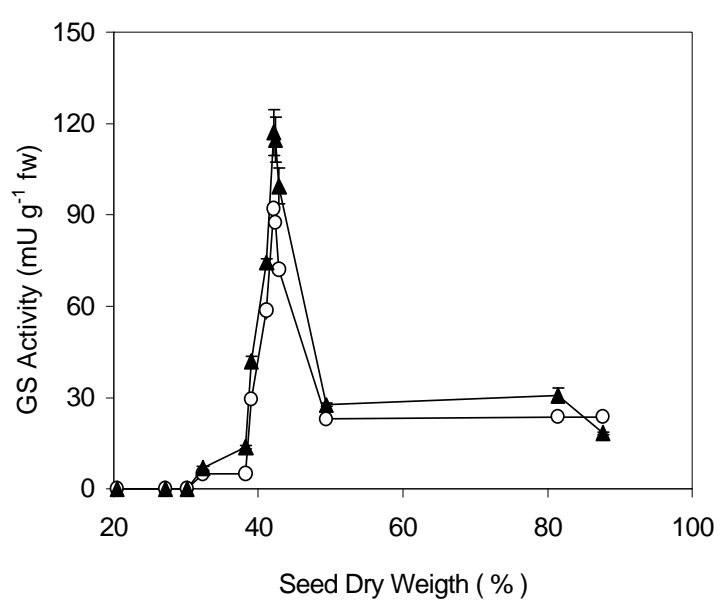

FIGURE 2 - Galactinol synthase activity in soybean seed at different developmental stages, as determined by the colorimetric method $(\boldsymbol{\Delta})$, and the isotopic method $(\mathrm{O})$.

enzyme was purified 46.3-fold to a specific activity of $66.35 \mathrm{mU} \mathrm{mg}^{-1}$ protein. SDS-PAGE analysis showed that the resulting GS sample contained several proteins with molecular masses ranging from 18 to $66 \mathrm{kDa}$ (not shown). The activity of the partially purified GS was maximal at $\mathrm{pH} 7.0$ (Figure 4A) and $50{ }^{\circ} \mathrm{C}$ (Figure 4B), but substantial activities were detected at extremes of $\mathrm{pH}$ (5-6 and 7.6-8.9). The optimal temperature is in agreement with the data reported for the Ajuga reptans GS enzyme which showed increasing activity with increasing temperature up to a maximum of $50^{\circ} \mathrm{C}$ (Bachmann et al., 1994). The $\mathrm{pH}$ and temperature profiles obtained for the partially purified enzyme match exactly that obtained with the enzyme sample resulting from the treatment of the seed extract with $\mathrm{MnCl}_{2}$ (Figure 4A,B). The optimal $\mathrm{pH}$ value is comparable to that reported for the GS enzyme from kidney bean cotyledons, which had an optimal pH of 7.0 (Liu et al., 1995), and to that reported for the enzyme purified from zucchini squash leaves, which had a broad $\mathrm{pH}$ optima from 7.0 to 8.0 , with activity dramatically decreasing below 6.5 and above 8.0 (Smith et al., 1991). 
TABLE 1 - Summary of the purification steps of soybean seed galactinol synthase. Enzyeme activity was assayed by the colorimentric method.

\begin{tabular}{lccccc}
\hline Purification Step & Total Protein & Total Activity & Specific Activity & Purification & Yield \\
& $\mathrm{mg}$ & $\mathrm{MU}$ & $\mathrm{mU} \mathrm{mg}^{-1}$ & Fold & $\%$ \\
\hline Crude extract & 16808 & 24122 & 1.44 & 1 & 100 \\
$\mathrm{MnCl}_{2}$ & 3864 & 29102 & 7.53 & 5.2 & 121 \\
DEAE-Sepharose & 1245 & 14647 & 11.76 & 8.2 & 61 \\
& & & & & \\
Phenyl-Sepharose & 228 & 11208 & 49.16 & 34.3 & 47 \\
Q-Sepharose & 109 & 7232 & 66.35 & 46.3 & 30 \\
\hline
\end{tabular}

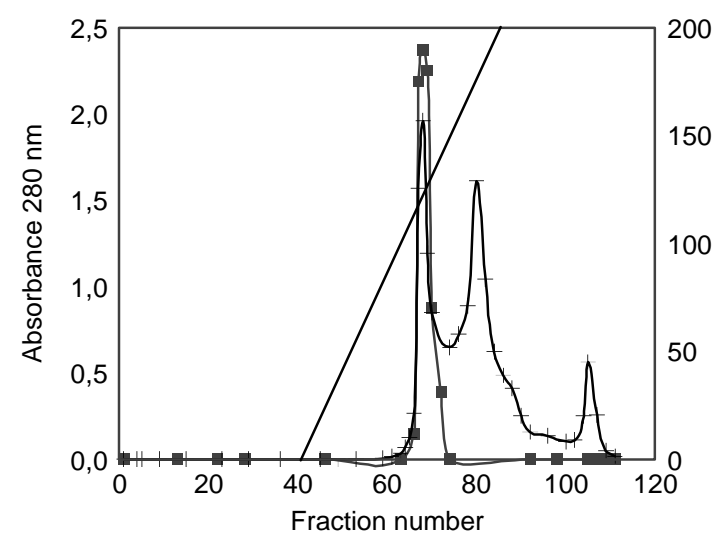

FIGURE 3 -Elution profile of soybean galactinol synthase on a Q-Sepharose column. Absorbance at $280 \mathrm{~nm}(+)$; enzyme activity ( $\square$ ) assayed by the colorimentric method; 0 - $0.5 \mathrm{M} \mathrm{aCl}$ gradient (-).

The activity of the partially purified GS enzyme was enhanced by $\mathrm{MnCl}_{2}$ (Figure 5) and DTT (not shown). These results are in agreement with those reported for the GS enzymes from Cucurbita pepo (Webb, 1982; Smith et al., 1991;
Liu et al., 1995) and kidney bean cotyledons (Liu et al., 1995). Cations were effective in inhibiting the GS enzyme, and $\mathrm{CuSO}_{4}(10 \mathrm{mM})$ and $\mathrm{CoCl}_{2}(1$ $\mathrm{mM}$ ) completely abolished the activity. On the other hand, however, $\mathrm{HgCl}(1 \mathrm{mM})$ did not affect the GS activity (Table 2). Inhibition of Cucurbita pepo (Webb, 1982) and zucchini squash leaves (Smith et al., 1991) by divalent cations has been previously reported.

Although the GS was fully active with the substrate UDP-gal it also hydrolyzed UDP-Glc, but not UDP-man and sucrose. $\mathrm{K}_{\mathrm{M}}$ and $\mathrm{V}_{\max }$ values calculated for UDG-gal using the colorimetric method were $5.2 \mathrm{mM}$ and 195 nmoles $\mathrm{min}^{-1}$, respectively, as determined by the algorithm for least squares estimation of non-linear parameters (Marquardt, 1979), or $2.0 \mathrm{mM}$ and 195 nmoles $\min ^{-1}$, respectively, as determined by the Lineweaver-Burk plot. For myo-inositol, $\mathrm{K}_{\mathrm{M}}$ and $\mathrm{V}_{\max }$ values of $3.5 \mathrm{mM}$ and 53.4 nmoles $\mathrm{min}^{-1}$, respectively, were determined by the algorithm mentioned above (Marquardt, 1979), and of 2.93 $\mathrm{mM}$ and 53.4 nmoles $\mathrm{min}^{-1}$, respectively, as determined by the Lineweaver-Burk plot. These 
values are comparable to the $\mathrm{K}_{\mathrm{M}}$ values of $1.8 \mathrm{mM}$ and $6.5 \mathrm{mM}$ reported for the conversion of UDPgal and myo-inositol, respectively, by GS purified from zucchini squash leaves (Smith et al., 1991). Nevertheless, these $K_{M}$ values are larger than those reported for conversion of UDP-gal $(0.4 \mathrm{mM})$ and myo-inositol $(4.5 \mathrm{mM})$ by a GS purified from kidney bean cotyledons (Liu et al., 1995).
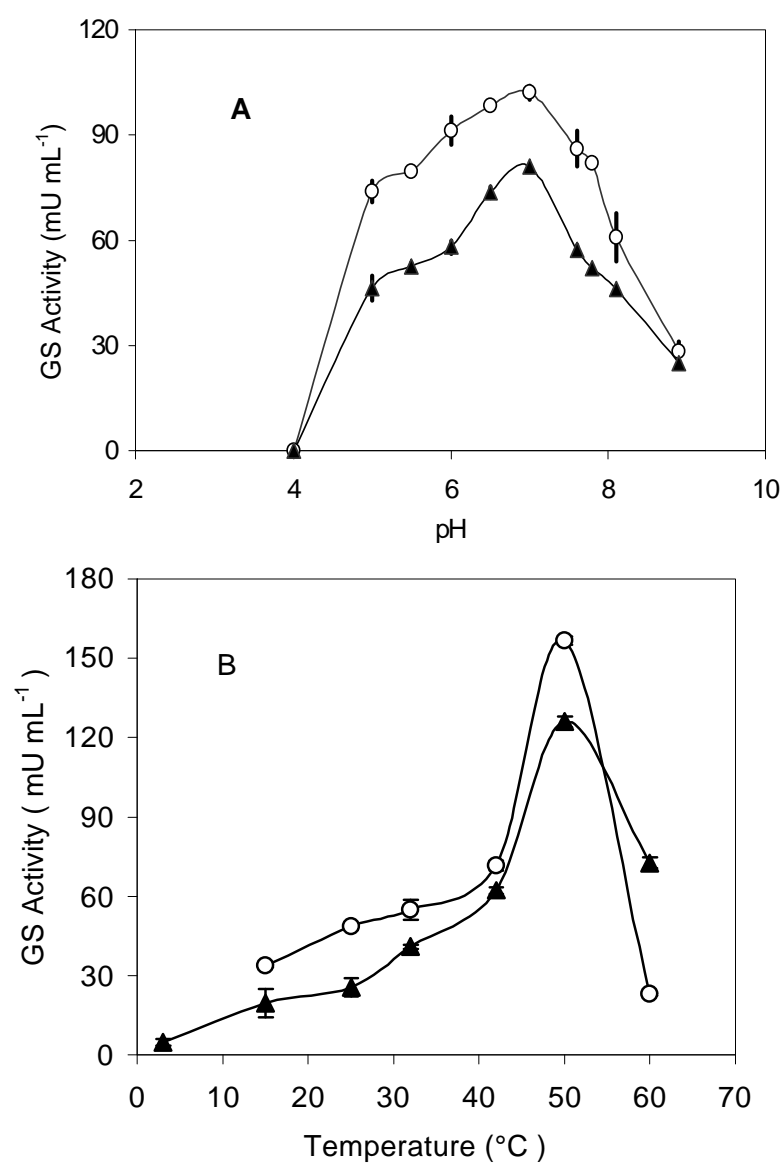

FIGURE 4 - Effect of pH (A) and temperature (B) on the activity of soybean galactinol synthase assayed by the colorimentric method. crude extract $(\boldsymbol{\Lambda})$; partially purified enzyme $(\mathrm{O})$.

Further kinetic and molecular characterization of soybean seed GS may be helpful for the understanding of its role in seed development. In addition, the gene encoding the GS enzyme may be useful for production of transgenic soybean plant with low capacity to produce the raffinose oligosaccharides, the causal agents of flatulence following leguminous seed ingestion. Additional work aiming at further purification and characterization of GS is being carried out.

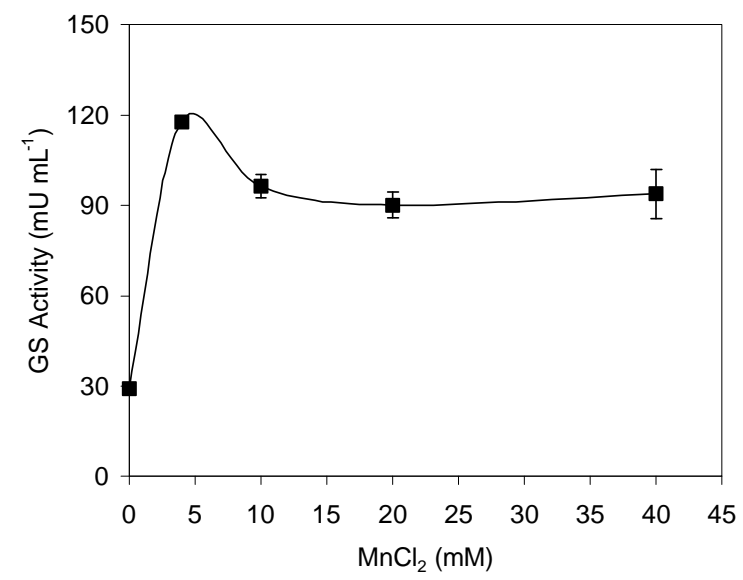

FIGURE 5 - Effect of $\mathrm{MnCl}_{2}$ on the activity of soybean seed partially purified galactinol synthase assayed by the colorimentric method

TABLE 2 - Effect of ions on the activity of soybean seed partially purified galactinol synthase assayed by the colorimentric method.

\begin{tabular}{lccc}
\hline Reagent & $\mathrm{mM}$ & $\begin{array}{c}\text { GS activity } \\
\left.(\mathrm{mU} \mathrm{mL})^{-1}\right)\end{array}$ & $\begin{array}{c}\text { GS relative } \\
\text { activity }(\%)\end{array}$ \\
\hline Control & - & $116.3 \pm 2.62$ & 100 \\
$\mathrm{ZnSO}_{4}$ & 1 & $101.6 \pm 5.69$ & 87 \\
& 10 & $36.8 \pm 3.52$ & 32 \\
$\mathrm{CuSO}_{4}$ & 1 & $113.4 \pm 8.16$ & 97 \\
& 10 & 0 & 0 \\
$\mathrm{AlCl}_{3}$ & 1 & $120.4 \pm 11.59$ & 104 \\
& 10 & $96.1 \pm 4.70$ & 83 \\
$\mathrm{FeCl}_{3}$ & 1 & $119.0 \pm 6.33$ & 102 \\
& 10 & $80.9 \pm 5.15$ & 70 \\
$\mathrm{CoCl}_{2}$ & 1 & 0 & 0 \\
$\mathrm{HgCl}^{2}$ & 1 & $117.4 \pm 4.29$ & 101 \\
\hline
\end{tabular}




\section{ACKNOWLEDGMENTS}

Mature seeds were kindly provided by Dr. Marcos Augusto Freitas-TEC AGRO, Brasília, DF. M.R. is grateful to the Universidade Federal de Viçosa and the Coordenação de Aperfeiçoamento de Pessoal de Nível Superior (CAPES) for financial support.

\section{REFERENCES}

BACHMANN, M.; MATILE, P. \& KELLER, F. Metabolism of the raffinose family oligosaccharides in leaves of Ajuga reptans. Cold acclimation, translocation, and sink to source transition: discovery of chain elongation enzyme. Plant Physiology, 105:1335-1345, 1994.

BLUM, H.; BEIER, H., \& GROSS, H. Improved silver staining of plant proteins, RNA and DNA in polyacrilamide gels. Electrophoresis, 8:93-99,1987.

CHATTERTON, N.J.; HARRISON, P.A.; THORNLEY, W.R. \& Bennett, J.H. SUCROSE OLIGOSACCHARIDES AND COOL TEMPERATURE GROWTH IN 14 FORB SPECIES. PLANT PHYSIOLOGY AND BIOCHEMISTRY, 28:167-172, 1990.

DEY, P.M. D-Galactoside containing oligosaccharides. In: Dey, P.M. AND Dixon, R.A. (Eds.) Biochemistry of Storage Carbohydrates in Green Plants. Academic Press, New York, 1985. p.53-129.

DINI, A.; SIMONE, F.; RAIMUNDO, R. \& SENATORE, F. Oligosaccharides in five different vicia faba cultivars. Biochemistry Systematic Ecological, 17:559-561, 1989.

FEHR, W.R.; CAVINESS, C.E.; BURMOOD, D.T. \& PENNINGTON, J.S. Stage of development descriptions for soybean, Glycine $\max$ (L) Merril. Crop Science, 11:929-931, 1971.
FISKE, C.H. \& SUBBAROW, Y. The colori-metric determination of phosphorous. Journal of Biological Chemistry, 66:375-400, 1925.

HANDLEY, L.W.; PHARR, D.M. \& McFEETERS, R.F. Relationship between galactinol synthase activity and sugar composition of leaves and seeds of several crop species. Journal of the Ameerican Society of Horticulture Science, 108:600-605, 1983.

HANDLEY, L.W. \& PHARR, D.M. Ion stimulation, UDP inhibition and effects of sulphydryl reagents on the activity of galactinol synthase from leaves of cucumber, Cucumis sativus L. Z. Pflanzenphysiology(?), 108:47-55, 1982.

KANDLER, O. \& HOPF, H. Occurrence, metabolism, and function of oligosaccharides. In: Preiss, J. (Ed.) The biochemistry of plants. A comprehensive treatise. Vol. 3. Carbohydrates: structure and function. New York, Academic Press, 1980. p.221- 270.

LAEMMLI, U. K. Cleavage of structural proteins during the assembly of the head of bacteriophage T4. Nature (London), 227:680$685,1970$.

LANZETTA, P.A.; ALVAREZ, L.J.; REINACH, P.S. \& CANDIA, O.A. An improved assay for nanomole amounts of inorganic phosphate. Analytical Biochemistry, 100:95-97, 1979.

LEE, C.Y.; SHALLENBERGER, R.S. \& VITTUM, M.T. Free sugars in fruits and vegetables. New York Food Life Science Bulletin, 1:1-12, 1970.

LIU, J.J.; ODEGARD, W. \& DE LUMEN, B.O. Galactinol synthase from kidney bean cotyledon and zucchini leaf. Purification and N-terminal sequences. Plant Physiology, 109:505-511, 1995.

LOWELL, C.A. \& KUO, T.M. Oligosaccharides metabolism and accumulation in developing soybean seeds.CropScience, 29:459-465, 1989. 
MARQUARDT, D. W. An algorithm for least squares estimation of non-linear parameters. Engineering Technology and Applied Sciences, 27:14-14, 1979.

MEYERHOF, O. The origin of the reaction of harden and young in cell-free alcoholic fermentation. Journal of Biological Chemistry, 157:105-109, 1945.

PHARR, D.M. \& SOX, H.N. Changes in carbohydrate and enzyme levels during the sink to source transition of leaves of Cucumis sativus L., a stachyose translocator. Plant Science Letter, 35:187-193, 1984.

RACKIS, J.; HONIG, D.H.; SESSA, D.J. \& STEGGERDA, F.R. Flavor and flatulence in soybean protein products. Journal of Agricultural and Food Chemistry, 18:977982, 1970.
SARAVITZ, D.M.; PHARR, D.M. \& CARTER, T.E. Galactinol synthase activity and soluble sugars in developing seeds of four soybean genotypes. Plant Physiology, 83:185-189, 1987.

SARKIS, J.J.F.; GUIMARÃES, J.A. \& RIBEIRO, J.M.C. Salivary apyrase of Rhodnius prolixus. Biochemistry Journal, 233:885-891, 1986.

SMITH, P.T.; KUO, T.M. \& CRAWFORD, C.G. Purification and characterization of galactinol synthase from mature zucchini squash leaves. Plant Physiology, 96:693698, 1991.

WEBB, J.A. Partial purification of galactinol synthase from leaves of Cucurbita pepo. Canadian Journal of Botany, 60:1054-1059, 1982. 